\title{
Faktor Risiko Lingkungan pada Pasien Japanese Encephalitis
}

\author{
I Gede E. Paramarta*, I Komang Kari*, Sunartini Hapsara** \\ * Bagian Ilmu Kesehatan Anak Fakultas Kedokteran Universitas Udayana \\ ** Bagian Ilmu Kesehatan Anak Fakultas Kedokteran Universitas Gajah Mada
}

Latar belakang. Penyakit Japanese encephalitis (JE) diperkirakan menjadi endemis di seluruh negara Asia, namun hanya sedikit kasus yang telah dilaporkan dari negara-negara tropis Asia seperti Indonesia, Malaysia, dan Pilipina. Di Indonesia terutama di Bali, penelitian mengenai faktor risiko lingkungan pasien JE pada manusia masih sangat terbatas.

Tujuan. Mengetahui peran sawah dan babi sebagai faktor risiko JE.

Metode. Suatu penelitian kasus-kontrol telah dilaksanakan Rumah Sakit Umum Pusat Sanglah, Bali, dari Januari 2005 sampai Desember 2007. Pasien usia kurang dari 12 tahun dan tinggal di Provinsi Bali dengan ensefalitis akut atau meningoensefalitis dimasukkan dalam penelitian. Hasil diagnosis JE ditetapkan dengan IgM virus-spesifik dalam cairan serebrospinal (CSS) dan serum, dengan metode IgM captures enzyme-linked immunosorbent assay (MAC ELISA).

Hasil. Empat puluh enam orang telah dimasukkan sebagai subjek penelitian, 23 disebabkan oleh JE. Sawah RR 4,68 (IK 95\% 1,29;16,98); $p=0,016$, babi RR 4,28 (IK 95\% 1,24;14,73); $p=0,018$ dan jarak kandang kurang dari 100 meter RR 8,00 (IK 95\% 1,27;50,04); $p=0,004$ berhubungan dengan terjadinya JE. Umur rerata pasien JE 65,52 (SD 32,54) bulan. Setelah dilakukan analisis multivariat, variabel sawah di sekitar tempat kediaman pasien menunjukkan hasil yang bermakna secara statistik RR 69,9 (IK $95 \%$ $1,55 ; 314,52) ; p=0,029$.

Kesimpulan. Sawah di sekitar tempat tinggal pasien merupakan faktor risiko Japanese encephalitis. (Sari Pediatri 2009;10(5):308-13).

Kata kunci: Japanese encephalitis, cairan serebrospinal, faktor risiko

$\mathrm{J}$

apanese encephalitis (JE) merupakan penyakit zoonosis akut yang disebabkan oleh virus Japanese encephalitis (VJE), menyebabkan radang otak

\section{Alamat Korespondensi:}

Dr. I Gede E. Paramarta, Bag/SMF Ilmu Kesehatan Anak FK UNUD RSUP Sanglah Denpasar, Jl. P Nias, tlp/Fax 0361-244038, Denpasar (ensefalitis) pada manusia melalui gigitan nyamuk yang akhirnya dapat menyebabkan kematian, cacat fisik, dan cacat mental. ${ }^{1,2}$ Penyakit JE merupakan problem kesehatan yang penting di Asia. Setiap tahun dari beberapa wilayah di Asia, lebih dari 35.000 kasus dilaporkan JE dan 10.000 di antaranya meninggal, ${ }^{3,4}$ walaupun jumlah kasus yang dilaporkan jauh lebih kecil dari kejadian yang sebenarnya. ${ }^{2}$ 
Siiniah $\mathrm{M}^{3}$ di Malaysia melaporkan kejadian JE merupakan penyebab ensefalitis yang paling sering dan belum mendapat sasaran imunisasi. Demikian juga di Indonesia, imunisasi terhadap JE belum dilaksanakan, terutama di Bali yang merupakan daerah dengan populasi ternak domestik dan wilayah pertanian yang luas. Mengingat penyebaran virus JE sangat tergantung dari beberapa faktor antara lain binatang perantara seperti babi, kera, burung dan lain-lain serta vektor (nyamuk). Vektor nyamuk Culex tritaeniorhynchus, $C x$ gelidus, dan Cx fuscocephala, dalam berkembang biak memerlukan tempat yang terdapat air yang tergenang dan tenang seperti sawah, selokan, dan tempat yang dapat menampung air kotor seperti ban bekas dan kaleng. Faktor umur, jenis kelamin, serta perlindungan diri dari gigitan nyamuk seperti penggunaan kelambu dan obat nyamuk diperkirakan juga sebagai faktor-faktor yang dapat mempengaruhi anak dari penyebaran VJE. ${ }^{4}$

Di daerah pedesaan Bali, babi merupakan salah satu ternak yang menjadi peliharaan di setiap rumah tangga dan merupakan mata pencaharian tambahan selain sebagai petani. Populasi babi sampai saat ini berdasarkan survei peternakan 1.558 .450 ekor pada tahun 2002 yang merupakan reservoar utama penyakit JE.

Selain itu Bali merupakan salah satu daerah agraris yang banyak memiliki sawah yang ada di setiap kabupaten. ${ }^{5}$ Untuk mengembangkan hasil pertanian terutama padi, maka dikembangkan sistem irigasi yang lebih baik dikenal dengan istilah subak, sehingga dalam satu tahun dapat menanam padi sampai tiga kali namun hal ini merupakan tempat yang baik untuk kembang biak nyamuk culex. ${ }^{6}$ Jenis nyamuk Culex yang terdapat di Bali antara lain $C x$ tritaeniorhynchus, $C x$ gelidus, dan $C x$ fuschophala.

Berdasarkan fakta tersebut dan karena keterbatasan data yang ada, terutama data faktor risiko lingkungan sekitar pasien JE di Bali, maka diperlukan penelitian tentang faktor risiko JE. ${ }^{6}$

\section{Metode}

Telah dilakukan penelitian kasus kontrol di RSUP Sanglah Denpasar dari Januari 2005 sampai dengan Desember 2007. Subjek penelitian adalah pasien usia 0 sampai 12 tahun yang didiagnosis sebagai ensefalitis virus akut atau meningoensefalitis, yang datang ke RSUP Sanglah. Secara klinis ensefalitis virus akut atau meningoensefalitis ditegakkan berdasarkan adanya demam (suhu aksila $>38^{\circ} \mathrm{C}$ ), manifestasi defisit neurologi (termasuk kesadaran menurun, defisit nervus kranialis, defisit sistem motorik dan sensorik) dan gejala kaku kuduk, kejang, dan ubunubun besar menonjol. Diagnosis akhir ensefalitis virus akut atau meningoensefalitis ditegakkan berdasarkan hasil pemeriksaan cairan serebrospinalis yaitu jernih, Nonne +/-, Pandy +/-, jumlah sel $10-100 / \mathrm{mm}^{3}$ dengan dominasi sel mononuklear, kadar glukosa normal dan peningkatan kadar protein.

Setelah informed consent ditandatangani orangtua yang telah menyetujui anaknya diikutsertakan dalam penelitian, dilakukan pemeriksaan cairan serebrospinal (CSS). Pasien dieksklusi apabila didapatkan kelainan neurologis yang berat, meningitis bakteri, sepsis, malaria, abses otak atau tumor.

Diagnosis ensefalitis virus akut atau meningoensefalitis JE ditegakkan berdasarkan kadar IgM virus yang spesifik pada CSS dan serum darah, dengan menggunakan IgM capture enzyme-linked immunosorbent assay (MAC ELISA). Positif JE jika anti-JE virus IgM ditemukan pada CSS (pengenceran 1:10) dengan titer $\geq 40$ unit. Pemeriksaan dilakukan di Laboratorium Kesehatan Daerah di Denpasar, Bali. Bila didapatkan hasil positif JE dipilih sebagai subjek penelitian kemudian dicarikan kasus kontrol dengan melakukan matching terhadap umur dan jenis kelamin. Berdasarkan perhitungan subjek dengan tingkat kemaknaan $\alpha<0,05$, power penelitian $80 \%$ dengan penetapan presisi $27 \%$, jumlah subjek penelitian yang diperlukan dalam penelitian minimal 23 dan kasus kontrol minimal 23 orang.

Penelitian bertujuan menilai peran babi dan sawah sebagai faktor risiko terjadinya JE dibandingkan dengan non JE. Hasil diuji dengan uji kai kuadrat dan uji Fisher serta menghitung risiko relatif (RR) dan interval kepercayaan 95\% (IK95\%). Variabel sawah, jarak sawah, babi, kandang babi, jarak kandang, obat nyamuk, dan kelambu dilakukan analisis multivariat. Analisis statistik menggunakan program komputer SPSS.

\section{Hasil}

Berdasarkan teknik pengambilan subjek secara konsekutif didapatkan 46 orang, 23 orang dalam kelompok kasus JE dan 23 orang termasuk kelompok kontrol. Ka- 
rakteristik dasar pada masing masing kelompok ditampilkan dalam Tabel 1, tidak ada perbedaan bermakna secara statistik antara kelompok kasus dan kelompok kontrol. Gejala klinis yang ditimbulkan sangat beragam antara lain demam, kesadaran menurun, kejang, muntah, dan kaku kuduk (Tabel 2.). Secara keseluruhan, hasil penelitian ditampilkan pada Tabel 3. Sawah RR 4,68 (IK 95\% 1,29;16,98); $p=0,016$, babi RR 4,28 (IK $95 \% 1,24 ; 14,73) ; p=0,018$ dan jarak kandang kurang dari 100 meter RR 8,00 (IK 95\% 1,27;50,04); $p=0,004$ didapatkan sebagai faktor risiko JE.

Setelah dilakukan analisis multivariat untuk menilai faktor risiko terjadi JE seperti sawah dan jaraknya, babi di sekitar tempat tinggal pasien, babi dikandangkan, memelihara babi dan ikut memelihara babi, didapatkan hanya variabel sawah di sekitar tempat tinggal pasien menunjukkan hasil yang bermakna

Tabel 2. Gejala klinis JE dan non JE

\begin{tabular}{lcc}
\hline Gejala klinis & \multicolumn{2}{c}{ Ensefalitis } \\
\cline { 2 - 3 } & JE, n (\%) & Non JE, n (\%) \\
\hline Demam & $23(100)$ & $23(100)$ \\
Kesadaran menurun & $23(100)$ & $23(100)$ \\
Kejang & $14(60,8)$ & $16(69,5)$ \\
Muntah & $4(17,3)$ & $11(47,8)$ \\
Kaku kuduk & $6(26,1)$ & $2(8,7)$ \\
\hline
\end{tabular}

Tabel 1. Karakteristik subjek penelitian

\begin{tabular}{|c|c|c|}
\hline \multirow[b]{2}{*}{ Karakteristik } & \multicolumn{2}{|c|}{ Ensefalitis } \\
\hline & $\underset{(n=23)}{J E}$ & $\begin{array}{c}\text { Non JE } \\
(\mathrm{n}=23)\end{array}$ \\
\hline Umur (bulan), rerata (SB) & $65,52(32,54)$ & $65,43(33,74)$ \\
\hline Jenis kelamin; laki, n(\%) & $15,0(65,2)$ & $15(65,2)$ \\
\hline \multicolumn{3}{|l|}{ Alamat } \\
\hline Negara, n(\%) & $0(0,0)$ & $1(4,3)$ \\
\hline Tabanan, $\mathrm{n}(\%)$ & $6(26,1)$ & $3(14,9)$ \\
\hline Singaraja, $\mathrm{n}(\%)$ & $1(4,3)$ & $0(0)$ \\
\hline Badung, $\mathrm{n}(\%)$ & $3(13,0)$ & $1(4,3)$ \\
\hline Gianyar, n(\%) & $7(30,4)$ & $3(13,0)$ \\
\hline Bangli, $\mathrm{n}(\%)$ & $0(0,0)$ & $1(4,3)$ \\
\hline Klungkung, n(\%) & $0(0,0)$ & $2(8,7)$ \\
\hline Karangasem, $\mathrm{n}(\%)$ & $2(8,7)$ & $4(17,4)$ \\
\hline Denpasar, $\mathrm{n}(\%)$ & $4(17,4)$ & $8(34,8)$ \\
\hline Berat $(\mathrm{kg})$, rerata $(\mathrm{SB})$ & $18,04(6,54)$ & $18,13(6,36)$ \\
\hline Status gisi (normal), $\mathrm{n}(\%)$ & $14(60,8)$ & $19(82,6)$ \\
\hline Tinggi $(\mathrm{cm})$, rerata $(\mathrm{SB})$ & $109,74(17,91)$ & $110,96(19,14)$ \\
\hline \multicolumn{3}{|l|}{ Tekanan darah } \\
\hline Sistolik (mmHg), rerata (SB) & $96,52(8,85)$ & $101,30(7,57)$ \\
\hline Diastolik (mmHg), rerata (SB) & $65,22(7,90)$ & $66,52(5,73)$ \\
\hline Nadi, (per menit), rerata $(\mathrm{SB})$ & $98,35(15,78)$ & $103,00(25,40)$ \\
\hline Respirasi (per menit), rerata (SB) & $33,26(14,60)$ & $33,74(6,39)$ \\
\hline Suhu $\left({ }^{\circ} \mathrm{C}\right)$, rerata $(\mathrm{SB})$ & $38,47(0,89)$ & $38,35(0,72)$ \\
\hline \multicolumn{3}{|l|}{ Laboratorium (Darah) } \\
\hline Leukosit $(\mathrm{k} / \mathrm{kl})$, rerata $(\mathrm{SB})$ & $12,24(10,09)$ & $9,80(4,20)$ \\
\hline Hemoglobin $(\mathrm{g} / \mathrm{dl})$, rerata $(\mathrm{SB})$ & $11,99(1,79)$ & $12,00(0,67)$ \\
\hline Hematokrit $(\%)$, rerata $(\mathrm{SB})$ & $36,05(5,19)$ & $35,87(2,23)$ \\
\hline Trombosit $(\mathrm{K} / \mathrm{ml})$, rerata $(\mathrm{SB})$ & $282,00(83,41)$ & $303,91(96,60)$ \\
\hline \multicolumn{3}{|l|}{ Laboratorium (CSS) } \\
\hline Glukosa likuor (mg/dl), rerata (SB) & $76,83(13,63)$ & $94,13(38,26)$ \\
\hline Sell $\left(/ \mathrm{mm}^{3}\right)$, rerata $(\mathrm{SB})$ & $48,96(45,93)$ & $12,09(14,16)$ \\
\hline Protein $(\mathrm{mg} / \mathrm{dl})$, rerata $(\mathrm{SB})$ & $43,96(21,28)$ & $49,39(59,44)$ \\
\hline Kelambu, n(\%) & $2(8,7)$ & $3(13,0)$ \\
\hline Obat nyamuk, n(\%) & $7(30,0)$ & $8(34,7)$ \\
\hline
\end{tabular}


I Gede E. Paramarta dkk: Faktor Lingkungan pada JE

Tabel 3. Faktor risiko JE di RSUP Sanglah Denpasar

\begin{tabular}{|c|c|c|c|c|c|}
\hline \multirow[t]{2}{*}{ Faktor risiko } & & \multicolumn{2}{|c|}{ Ensefalitis } & \multirow[t]{2}{*}{ RR (IK 95\%) } & \multirow[t]{2}{*}{$p$} \\
\hline & & JE & Non JE & & \\
\hline \multirow[t]{2}{*}{ Sawah di sekitar rumah } & Ya & 18 & 10 & $4,68(1,29-16,98)$ & $0,01^{a}$ \\
\hline & Tidak & 5 & 13 & & \\
\hline \multicolumn{6}{|l|}{ Jarak sawah (meter) } \\
\hline $0-100$ & & 12 & 2 & $8,00(1,27-50,04)$ & $0,04^{b}$ \\
\hline$>100-400$ & & 6 & 8 & & \\
\hline \multicolumn{6}{|l|}{ Terdapat babi di sekitar } \\
\hline \multirow[t]{2}{*}{ rumah } & Ya & 16 & 7 & $4,28(1,24-14,73)$ & $0,01^{a}$ \\
\hline & Tidak & 8 & 15 & & \\
\hline \multirow[t]{2}{*}{ Kandang babi* } & Ya & 11 & 7 & $0,31(0,03-3,28)$ & $0,62^{\mathrm{b}}$ \\
\hline & Tidak & 5 & 1 & & \\
\hline \multicolumn{6}{|c|}{ Jarak kandang babi* (meter) } \\
\hline $0-100$ & & 8 & 4 & $2,00(0,27-14,78)$ & $0,62^{\mathrm{b}}$ \\
\hline$>100-400$ & & 3 & 3 & & \\
\hline
\end{tabular}

${ }^{a}$ Uji Kai Kuadrat; ${ }^{b}$ Uji Fisher * Sub analisis

Tabel 4. Faktor risiko JE*

\begin{tabular}{lcccccc}
\hline \multicolumn{1}{c}{ Variabel } & $\beta$ & SE & Wald & $p$ & RR & IK 95\% \\
\hline Terdapat sawah & 4,2 & 1,9 & 4,7 & 0,02 & 69,9 & $1,5-314,5$ \\
Jarak sawah & 1,6 & 1,1 & 2,3 & 0,12 & 5,2 & $0,6-44,2$ \\
Terdapat babi & 2,4 & 1,6 & 2,1 & 0,14 & 11,6 & $0,4-300,7$ \\
Kandang babi & 0,3 & 1,6 & 0,0 & 0,82 & 1,4 & $0,05-40,6$ \\
Jarak kandang & 0,4 & 0,9 & 0,2 & 0,62 & 1,6 & $0,2-11,4$ \\
Obat nyamuk & 0,01 & 0,9 & 0,0 & 0,99 & 1,1 & $0,1-6,2$ \\
Kelambu & $-1,5$ & 1,2 & 1,5 & 0,21 & 0,2 & $0,02-8,1$ \\
\hline
\end{tabular}

${ }^{*}$ multivariat regresi logistik

secara statistik dengan RR 69,9 (IK 95\% 1,55;31,52); $p=0,029$ (Tabel 4).

\section{Diskusi}

Penelitian sebelumnya melaporkan hubungan antara hewan domestik salah satunya babi serta sawah dengan terjadinya JE. Di daerah Arcot selatan (Tamil Nadu), 39\% kasus menyerang anak-anak umur 4-6 tahun dan $28 \%$ pada umur 7-9 tahun. ${ }^{6}$ Pada penelitian kami berdasarkan umur rata-rata pasien didapatkan pada kelompok kasus 65,5 bulan. Demikian juga penelitian yang dilakukan oleh $\operatorname{Kari}^{7}$ mendapatkan kelompok umur terbanyak 4-6 tahun (60\%). Pada umur ini pasien sudah dapat bermain keluar rumah, terutama sore hari oleh karena nyamuk Culex menggigit sore hari sampai sebelum matahari terbenam. Jenis kelamin pasien JE antara laki-laki dan perempuan hampir sama di beberapa negara, seperti di Thailand, India, Nepal, dan Cina, rasionya berturut-turut yaitu 1,3:1, 1:0,63, 1,7:1,1 dan 4:1.13,14 Pada penelitian kami didapatkan jenis kelamin pada pasien JE 65,2\% laki-laki, pada penelitian Kari mendapatkan laki-laki 60\%. ${ }^{7}$

Pada individu yang rentan, VJE menyerang sistem saraf pusat, seperti parenkim otak dan meningen melalui suatu proses yang sangat kompleks. Virus JE masuk dan mengalami replikasi di dalam neuron dan meningen, menyebar dengan cepat sehingga mengakibatkan gejala klinis JE seperti demam, penurunan kesadaran, gejala rangsang meningeal seperti kaku kuduk, muntah, kejang, dan nyeri kepala.,11

Bali merupakan daerah yang memiliki luas daratan sekitar 5.632,86 km2. Dari luas tersebut sekitar 15,2\% merupakan daerah persawahan yang tersebar di seluruh kabupaten. Penggunaan air untuk daerah tersebut sangat efisien, dalam satu tahun dapat dilakukan tiga kali penanaman padi. ${ }^{8}$ Untuk mengatur pengairan sawah dibuat sistim irigasi unik yang hanya terdapat di Bali yang dikenal dengan sistem subak, ${ }^{1,3}$ sehingga dimungkinkan dalam mananam padi menggunakan tatacara pengaliran terus menerus dan penggenangan terus menerus. ${ }^{9,10}$

Sesuai dengan hasil penelitian yang dilakukan didapatkan bahwa faktor sawah sangat berkaitan dengan kejadian JE yaitu meningkatkan kejadian 
JE 4,68 kali dibandingkan dengan tidak adanya sawah di sekitar tempat tinggal pasien. Hal ini sesuai dengan praktek pola tanam yang dilakukan di Bali dengan sistem subak, ${ }^{8,9}$ sangat sesuai dengan pola siklus hidup nyamuk Culex untuk dapat berkembang biak. Siklus hidup nyamuk memerlukan waktu untuk berkembang biak selama kurang lebih sebulan, sehingga waktu untuk pengairan menjadi hal yang sangat menguntungkan bagi perkembang biakan nyamuk Culex..$^{11,12,13}$ Jarak antara sawah dengan tempat tinggal pasien memiliki hubungan dengan kejadian JE, jarak kurang dari 100 meter memiliki kesempatan untuk menderita JE lebih besar dibandingkan dengan yang berjarak lebih dari 100 meter. $^{7}$ Hal ini sesuai dengan hasil penelitian kami $(p=0,04)$. Kemampuan terbang nyamuk Culex berkisar kurang lebih 100 meter sehingga memungkinkan nyamuk berkembang biak pada sawah untuk terbang mencapai tempat tinggal pasien. ${ }^{13}$ Kari pada penelitiannya mendapatkan jarak antara babi dan sawah dengan rumah pasien kurang dari 100 meter. $^{7}$

Ditemukan babi yang dipelihara di sekitar rumah pasien akan meningkatkan faktor risiko terjadinya JE 4,28 kali dibanding tidak ada babi di sekitar tempat tinggal pasien. Babi merupakan salah satu hewan favorit sebagai hewan domestik peliharaan. Jumlah babi yang dipelihara pada tahun 2000, 1.558.450 ekor di seluruh Bali tersebar di setiap daerah pedesaan. Hampir setiap keluarga memiliki babi sebagai mata pencaharian tambahan baik yang dikandangkan maupun tidak. ${ }^{8}$ Penelitian yang dilakukan oleh Kari ${ }^{7}$ juga mendapatkan bahwa babi sebagai faktor risiko terjadinya JE. Selain itu isolasi virus telah dilakukan di peternakan babi di Jakarta menunjukkan hasil nyamuk Culex sebagai vektor utama dan babi sebagai amplifiying host. Nyamuk Culex telah banyak dapat diisolasi di peternakan babi sehingga terdapat hubungan yang sangat kuat antara nyamuk Culex dengan JE. ${ }^{12} \mathrm{Babi}$ yang terdapat di sekitar pasien baik dikandangkan atau tidak, tidak ada perbedaan yang bermakna sebagai factor risiko. Penelitian lain belum didapatkan hasil tentang pengandangan babi.

Dalam analisis multivariat untuk menilai faktor risiko terjadinya JE seperti sawah dan jaraknya, babi di sekitar tempat tinggal pasien, babi dikandangkan, memelihara babi dan ikut memelihara babi, dijumpai sawah di sekitar tempat tinggal pasien menunjukkan risiko yang bermakna secara statistik (70 kali). Temuan ini sesuai dengan penelitian yang dilakukan oleh
Kari $^{7}$ yang mendapatkan sawah berhubungan dengan kejadian JE.

Babi bukan menjadi faktor risiko disebabkan oleh karena sebagai amplifying host tidak cukup dapat menyebarkan VJE ke manusia, tetapi faktor nyamuk dalam hal ini sawah sebagai tempat berkembang biaknya menjadi faktor yang lebih penting, karena tanpa perantara nyamuk VJE ini tidak dapat menginfeksi manusia. ${ }^{13}$

Penyakit zoonosis pada dasarnya adalah penyakit dari hewan ke hewan. Virus JE dapat menyerang manusia oleh karena nyamuk yang terinfeksi VJE secara kebetulan menggigit manusia. Populasi nyamuk yang terlalu padat serta nyamuk betina yang harus bertelur memerlukan makanan (darah) yang kebetulan menggigit babi dan manusia. Tetapi tidak semua manusia yang terinfeksi menjadi sakit, hanya 1 dari 400-1000 yang terinfeksi akan menunjukkan gejala klinis, oleh karena kebanyakan infeksi yang terjadi dapat teratasi oleh tubuh sebelum virus menginvasi susunan saraf pusat (SSP) dan hanya menimbulkan gejala sub klinis. ${ }^{12,14,15}$

Terdapat beberapa keterbatasan pada penelitian kami karena subjek yang diteliti berawal dari rumah sakit, sehingga kurang menggambarkan keadaan yang sebenarnya dalam masyarakat. Selain itu dapat terjadi recall bias dalam pengisian kuisioner oleh orangtua pasien. Berdasarkan hasil penelitian, disimpulkan bahwa sawah di sekitar tempat tinggal pasien merupakan faktor risiko penularan penyakit JE.

\section{Daftar Pustaka}

1. Dinas Peternakan Propinsi Bali. Kebijakan dan prosedure baku pengendalian penyakit menular yang diduga JE di propinsi Bali. Seminar klarifikasi dan formulasi format strategi penanggulangan penyakit yang diduga JE. Denpasar: Dinas Peternakan Propinsi Bali; 2002. h. 1-8.

2. Becker DP, Bharcca EP. Japanese encephalitis. Neurol in Clin Prac 1992;2:1926-7.

3. Siiniah MA. Review of Japanese B encephalitis in Malaysia. S As J Trop Med Pub Health 1989;20:581-5.

4. Monath TP. Japanese encephalitis. Dalam: Strickland GT, penyunting. Hunter's tropical medicine. Edisi ke-7. Philadelphia: W.B. Saunders Company; 1991. h. 229-31.

5. Reuben R, Gajanana A. Japanese encephalitis in India. Indian J Pediatr 1997;14:243-51. 
6. Kumar R, Mathur A, Kumar A, Sharma S, Chakrabortys, Chaturvedi MC. Clinical Features and prognostic indicator of Japanese Encephalitis in children in Lucknow (India). Indian J Med Res 1990;91:321-7.

7. Kari K, Gautama K, Wei L, Zhi Yi Zu. Japanese Encephalitis di Bali. Naskah Lengkap Pendidikan Kedokteran Berkelanjutan. 2003:57-66.

8. Badan Pusat Statistik. Pertanian. Dalam: Badan Pusat Statistik Propinsi Bali, penyunting. Bali dalam angka 2000. Denpasar: BPS Propinsi Bali; 2001. h. 135-202.

9. Departemen Pertanian RI. Pedoman Bercocok Tanam. Padi Palawija Sayur-sayuran. Departemen Pertanian satuan Pengendali Bimas. 2003;157-161.

10. Departemen Pertanian RI. Petunjuk lapang. Pengelolalan tanaman terpadu padi sawah, Balai Pengkajian dan
Pengembangan Teknologi Pertanian. 2004;23-7.

11. Tiroumourougane SV, Raghava P, Srinivasan S. Japanese viral encephalitis. Postgrade Med J 2002;78:205-15.

12. Mackkezie JS, Johansen CH, Ritchie SA, Hurk AF, Hall RA. Japanese Encephalitis in an emerging virus: The emergence and spread of Japanese Encephalitis virus in Australasia. Dalam: Mackkezie JS, Barret, penyunting. Japanese encephalitis and West Nile viruses. Germany: Springer-Verlag Berlin Heidelberg; 2002. h. 49-74.

13. Service MW. Cilicine Mosquitoes (Culicinae). Med Ento 1996;15:55-8.

14. Hill MG. Viral infection of the central nervous system. Dalam: Rudolph penyunting. Rudolph's pediatrics. Philadelphia: Lippincot William \& Wilkins; 2001. h. 2305-8. 